\title{
Entrepreneurship Ecosystem and Development of Entrepreneurship in Pakistan
}

\author{
Mahendar Kumar \\ Greenwich University, Karachi, Pakistan \\ Email: mahendarbajaj101@gmail.com
}

How to cite this paper: Kumar, M. (2020) Entrepreneurship Ecosystem and Development of Entrepreneurship in Pakistan. Open Journal of Business and Management, 8, 1734-1770.

https://doi.org/10.4236/ojbm.2020.84109

Received: December 20, 2019

Accepted: July 25, 2020

Published: July 28, 2020

Copyright (อ 2020 by author(s) and Scientific Research Publishing Inc. This work is licensed under the Creative Commons Attribution International License (CC BY 4.0).

http://creativecommons.org/licenses/by/4.0/

(c) (i) Open Access

\begin{abstract}
The study has been taken in order to explore the concept of entrepreneurship ecosystem and how the development of ecosystem model has an impact on the development of entrepreneurship in Pakistan. Hence, the top-down and bottom up approach both were used simultaneously in order to comprehend the entrepreneurship ecosystem phenomenon under investigation. The entrepreneurship ecosystem has been analyzed through SMEDA SME policies, cultural tendency and private educational institutions' capacities in Pakistan in the quantitative part of the study. This study is however, guided by Isenberg (2011) and Mason and Brown (2014) through their scholarly work on entrepreneurship and entrepreneurship ecosystem. The mixed methods research strategy and parallel convergent design were used to understand and explore the phenomenon and hence quantitative and qualitative data were collected simultaneously. Although, the quantitative data were collected through convenience sampling from six universities, interviews were conducted at the same time from academic professionals, incubation center representatives and entrepreneurs as well. The quantitative data were then analyzed through SPSS and qualitative data through trial version of NVivo 12. The quantitative results show the significant relationship between SMEDA SME policies and development of entrepreneurship; however, the strength of relationship was considered to be weak. Similarly, the significant relationship was also found between cultural tendency and development of entrepreneurship in Pakistan; however strength of relationship was also weak. Moreover, the significant relationship was found between private educational institutions' capacities and development of entrepreneurship but, the strength of relationship was weak in nature. However, while testing the final hypothesis, the relationship between cumulative SMEDA policies, cultural tendency, private educational intuitions' capacities and entrepreneurship development in Pakistan was also found with moderate strength of association. While converging the data from quantitative and qualitative part, it was observed that,
\end{abstract}


both data do converge at some point, because factors emerged in the qualitative data (family system, educational system, entrepreneurial attributes, and legal framework and incubation centers) and the results found in the quantitative data do find the relationship between with the entrepreneurship ecosystem and the development of entrepreneurship in Pakistan.

\section{Keywords}

SMEDA Policies, Cultural Tendency, Private Educational Institutions, Parallel-Research Design, Ecosystem

\section{Introduction}

The research is intended to understand the impact of entrepreneurship ecosystem on the development of entrepreneurship in Pakistan in terms of its cultural factors, SMEDA policies by government of Pakistan and institutional capacities including both public and private ones. Hence, it is quite imperative to dissect here the meaning of "Entrepreneurship ecosystem". Pakistan, as similar to other low, middle and high income countries, consists of high number of SMEs, which generate majority of jobs in the country and contribute up to $40 \%$ in the GDP of Pakistan (Zafar \& Mustafa, 2017). Although, the entrepreneurship concept is not new, it was Joseph Schumpeter who defined entrepreneurship first time in terms of its innovation applicability in 1911 through his second book called "The theory of economic development" (Bazhal, 2017). Later on, he defined entrepreneurship as the methodology to create novel products, new ways to produce the already manufactured products through the use of latest technology or to find new markets or sources of supply for the existing products (Schumpeter, 1934). Schumpeter was also the one who introduced the concept of creative destruction and its benefits for the economy (Gunter, 2012). However, entrepreneurship is recently defined by numbers of scholars as an endeavour to find new opportunities and exploit those opportunities in order to offer new products and services in the market and managing them in a way, that didn't happen before (Venkataraman, 1997; Shane \& Venkataraman, 2000). But, basically even today, there are two schools of thoughts that prevail in the realm of entrepreneurship since the earlier $20^{\text {th }}$ century. Although, it is quite fascinating to discover that however, Schumpeterian and Kirznerian entrepreneurship both were under the influence of Austrian school of thought in one way or the other but; both took a different perspective of entrepreneurship phenomena (Andrieu, 2010). While Schumpeter based his theory on the basis of technological change with the concept of producing new products, finding new markets and having an external agent that disturbs the equilibrium position in the market, on the other hand, Kirzner (1973) argued that an entrepreneur is someone who is alert and finds possibilities in the current market structure through the knowledge gap and that 
gap is actually exploited by an individual or potential entrepreneur in order to generate profit so, the market equilibrium is disturbed internally (De Jong \& Marsili, 2010).

Moreover, ecosystem was first defined in biological science by Sir Arthur Tansley in 1935 and then later on, social sciences adopted the phenomena because of its core importance. Ecosystem is defined as an environment in which living organisms interact with the non-living organisms or how living organisms interact with their immediate physical surroundings (Pickett \& Cadenasso, 2002). Similarly, entrepreneurship ecosystem is expounded as an environment in which interrelated agents (private and public institutions) and factors (social, political and cultural) interacts in such a way, that facilitates the entrepreneur to start his/her new venture in a particular territory (Stam \& Spigel, 2016). It is also defined as system that is combination of those agents linked together at a specific place, including educational institutions, governments, investors, professional service providers form a vibrant, open environment through which, all those connected can help and support each other objectives (Yaribeigi et al., 2014). However, entrepreneurship ecosystem is also made up of three key factors, first, there is a critical mass of entrepreneurs, companies, and institutions specialized in a particular location, second, there is an already established dense network of relationships between the agents and last but not the least, there is a culture through which all agents are interacted (Isenberg, 2011). Therefore, this study is intended to explore and explain the idea of entrepreneurship ecosystem and to find its influence on development of entrepreneurship in Pakistan through mixed methods research methodology.

\section{Problem Statement:}

It has been empirically found and observed that, small firms play a key role in the economic growth and development globally as the knowledge economy concept has been prevalent in the current era (Braunerhjelm, 2010). Pakistan is no different in this regard, there is a large number of small and medium sized enterprises exist in Pakistan that do absorb most of the non-rural population but, their contribution in the GDP is not as much impressive as it should be (as in the case of Taiwan and Hong Kong) (Zafar \& Mustafa, 2017). In addition to that, the concept of entrepreneurship is still new in Pakistan because the idea of opening your own business/venture rather than getting a decent job is not accepted wholeheartedly in the culture. Hence, the interconnectedness of different institutions (public and private), factors (cultural or organizational) and processes (the business birth rate, high growth firms (HGF) etc. support the environment for entrepreneurship activity (ecosystem) is still in its nascent form (Pakistan Entrepreneurship Ecosystem Report, 2014).

That is why; this research will explore the idea of entrepreneurship ecosystem in terms of SMEDA policies, cultural tendency and private institutions' capacities and would strive to understand their impact on the development of entrepreneurship in Pakistan. 


\section{Hypothesis:}

$\mathrm{H} 1=$ There is a significant relationship between SMEDA policies and entrepreneurship development in Pakistan

$\mathrm{H} 2=$ There is a significant relationship between cultural tendency and entrepreneurship development in Pakistan

$\mathrm{H} 3$ = There is a significant relationship between private educational institutions' capacities and entrepreneurship development in Pakistan

H4 = There is a significant relationship between cumulative SMEDA policies, cultural tendency, private educational intuitions' capacities and entrepreneurship development in Pakistan

\section{Qualitative Questions:}

1) How do you define entrepreneurship ecosystem in your own terms?

2) What do you think about SMEDA policies and their role in the development of entrepreneurship in Pakistan?

3) What is your opinion about the cultural tendency; does our culture support/discourage the idea of entrepreneurship in Pakistan?

4) What do you think regarding the private educational institution's capacities (like university) and its contribution in the development of entrepreneurship in Pakistan?

5) In your opinion, if we devise more entrepreneur friendly SMEDA policies, conductive cultural environment and appropriate private educational institution's capacities, would the amalgamation of these all three, contribute to the development of entrepreneurship in Pakistan?

6) How do you perceive the impact of entrepreneurship ecosystem on the development of entrepreneurship in Pakistan?

\section{Objectives of the study:}

1) To understand how SMEDA policies can play their role in the development of entrepreneurship in Pakistan

2) To understand how the private institutions can contribute to the development of entrepreneurship in Pakistan

3) To understand how culture can influence the development of entrepreneurship in Pakistan

4) To elaborate the entrepreneurship ecosystem and the contributing factors into the development of entrepreneurship ecosystem in Pakistan

5) To find out the relationship between entrepreneurship ecosystem and development of entrepreneurship in Pakistan

\section{Literature Review}

There are normally four ways to write the literature review and it all depends on the kind and purpose of the particular research and literature review (Creswell, 2014). This research will use one of the methods mentioned above and that is the integration of past studies in order to find the knowledge gap. Jegede (1990) defined entrepreneurship as a vibrant energy that mobilizes other resources to ful- 
fill the needs and demands of needy market. Banjoko (2002) further elaborated the concept by arguing that, it is of creating value by putting together all kinds of idiosyncratic resources and skills to exploit an opportunity. Entrepreneurship is also the disposition of an entrepreneur to find an investment opportunity, open a firm to exploit that opportunity, run that firm successfully either for getting profit or social benefit (Drucker, 1985). Entrepreneurship ecosystem usually includes individuals, groups, organizations and institutions which form a community by having interaction with each other. Ecosystem is an environment where all those actors work and interconnect and also forms the infrastructure that influences on their working relationship through laws, culture and policies (Giz Report, 2014). Entrepreneurship ecosystem on the other hand is defined as a collection or combination of multiple actors working together in order to create an environment in which, the cause of entrepreneurship can thrive (Yaribeigi et al., 2014). Those actors can be entrepreneurial organizations, government organizations, venture capital firms, large businesses, universities, incubation centers and business advisory and legal consulting firms (Mason \& Brown, 2014).

However, it was Daniel Isenberg who initially gave the most logical and influential model of entrepreneurship ecosystem while connecting its features with the economic growth and development of any country. He identified six elements as key determinants those more or less determine the dynamics of entrepreneurial ecosystem. Those factors are: favourable culture, workable policies, financial availability, capable human resource, enabled market mechanism and subsequently a range of institutional support (Isenberg, 2011). However, there is also another model termed as FORA model, which emphasized on the role of "blockbuster entrepreneurship", it is a successful entrepreneurial startup that has climbed the ladder in the organizational structure and hence produced enough wealth for its founders, investors, senior management and employees. According to FORA, when those folks maintain a continuous involvement in the ecosystem through reinvesting their experience and wealth as mentors, investors and serial entrepreneurs, build a stronger ecosystem at the end of the day. FORA group also introduced the term called "deal-makers" and these are the individuals who play a central role in this process of information sharing (Napier \& Hansen, 2011). These deal makers are characterized as well-connected and experienced businessmen who have the skills, know-how and connections to people and resources to support young companies (Mason \& Brown, 2014). However, the inter-mixing of those key factors mentioned by two models can enable an entrepreneur to exploit an opportunity and produce impact in the society whether through profit seeking or social cause. However, there are two models of entrepreneurship those are followed by most the entrepreneurs today: causal model and effectual model. The causal way of entrepreneurship leads to the pre-planned sequential list of steps needed to achieve a particular goal in sight. The examples can be financial and sales forecasting for 5 to 10 years and then based on that forecasting, all other strategic planning is done, however effectual 
kind of entrepreneurship on the other hand, doesn't require that kind of planning but just enough means to achieve a goal because the means and goals are not fixed, they can change over time depending on the availability of resources and the value of goal itself (Sarasvathy, 2008). The effectual entrepreneur is different from the one following causal model because, that entrepreneur is not just expert in his/her domain but willing to take risk, show spontaneity and possess the skills of situational leadership. That entrepreneur has normally three qualities, first, he/she knows himself/herself better than others do, they have the knowledge and experience in their domain and they have the contacts necessary to execute their idea well, they don't plan everything in advance but just one step at the time (Sarasvathy, 2008). Hence, this research has explored both models in the context of Pakistan and tried to find out their importance from the different stakeholders through face to face interviews.

The model that is followed by an entrepreneur also depends on the culture; culture does play a critical role in entrepreurship development (Abzari \& Safari, 2010). Laužikas and Mokšeckienè (2013) have presented culture as the one through which multiple ideas about the world and life emerge and people's culture is their life, their spontaneity, their creation of spiritual values and their meaning of life. Hence, culture determines the behaviors, the mindset of individuals those characteristics play a key role in the development of entrepreneurship in any country. Psychological traits are also essential because, individuals are different in their thinking and doing things, society with more entrepreneurial thinking can develop more entrepreneurs (Davidsson, 1995). However Hofstede (1991) was the one who dissected the concept of culture and divided it into four distinct features. He defined culture as a collective mindset of a group or a clan that is different from other groups or clans. He then elaborates that by emphasizing on the shared values and norms of one group as different as other groups. People having shared norms and values socialize with each other and hence emerge appropriate and inappropriate behaviors, those eventually impact on the entrepreneurship because the behaviors are the product of underlying norms and values. Hence, he identified four traits that separate one culture from another, power distance, individualism, masculinity and uncertainty avoidance (Russell, 1997).

It has observed that entrepreneurship mindset is influenced mainly by two institutions: Family and education. Entrepreneurship education has got the attention in formal institutions recently because it can reduce unemployment and poverty as well, as the unemployed can start their own business and generate wealth through different business activities (Mariana-Cristina, 2014). Family on the other hand can support the individual emotionally and financially if possible in order to motivate him/her to move forward in their respective lives and contribute through their skills and knowledge. It can also facilitate the access of social networks needed to start any kind of business along with knowledge regarding suppliers, buyers and marketing know-how (Dyer \& Handler, 1994; Reyn- 
olds et al., 2004). Entrepreneurship education on other hand, contribute in developing attitudes, beliefs, skills and capacities necessary to start any new business./venture and then expand it slowly and gradually (Akhuemonkhan, 2005). Entrepreneurship education is also a process of creating a mindset that can use creative thinking and innovative approach in order to solve recognizable and complex problems, or improving the micro or macro systems in which they dwell (Eze, 2011). Entrepreneurs don't do business in vacuum but they are part of the social structure hence, networks do play an important role in their success or failure. There is an approach called the social network approach, it suggests that the relationships between entrepreneurs and other related agents in the marketplace supply the resources that are essential in establishing a business (Johannisson, 1988; Larson, 1991). It also argues that, entrepreneurs do have ideas to test, and the knowledge and skills to operate the business, but they also need complementary resources to produce and deliver their goods or services (Teece, 1987). Hence, they have to get support, knowledge, and access to distribution channels through their social networks, therefore, they are connected to other people and organizations and the interaction among those all, can increase the availability of resources that can help to sustain a new firm (Hansen, 1995).

The entrepreneurs do function in an environment and government of any country is the major stakeholder of that environment as it can facilitate the players in a good and logical way. Government policy can reduce the constraints faced by entrepreneurship (Acs et al., 2004). In Pakistan, there are a number of institutions (e.g. SMEDA, State bank of Pakistan, SME bank and etc.) that support the SME sector, one of them is discussed in this study is SMEDA (small and medium enterprises development authority) and its policies for entrepreneurship development. However, general government SME policy is the one that has the main target of providing favourable regulations that improve the conditions of SMEs and hence produce enabling environment and supportive system for them. Although, one of the government functions can be to facilitate creating business incubation centers in which a new startup can find supportive structure (in the form of critical tools, mentorship, contacts, capital and other resources) and can survive and thrive (Tötterman \& Sten, 2005). Commonly, it is perceived that governments try to support HGFs (high growth firms) and usually focus on five key areas: general perspective of entrepreneurship, tax and regulatory climate, access to capital, entrepreneurship education and intellectual capital (Kayne, 1999).

In Pakistan, SMEDA (Small and Medium Enterprise Development Authority) is the organization that supports the entrepreneurship through its vision of producing "Globally competitive SME sector, through a business friendly environment and support services, serving as an engine of sustainable growth for national economy". Hence it has created the SME policy in 2007, which emphasized on the following key points:

1) SME in Pakistan is defined in terms of number of employees up to 250 
people, paid-up capital up to Rs.25 million and annual sales up to Rs.250 million (SMEDA SME Policy, 2007).

2) It has focused on issues of business environment, human resource development, support for technology upgrading and marketing.

3) It has also covered implementation and monitoring mechanism of policy measures

4) Capacity building of public institutions

5) Resource allocation and potential sources of funding

6) Linkages with other initiatives and public sector reform processes

7) Role of different stakeholders (Public \& Private) at federal, provincial and local level

There are some critics of this policy like it has provided the information regarding the regulations affecting SME sector but, it has not emphasized on the need of reducing those regulations and how the people implementing those regulations should be trained, how public-private partnership can improve SME sector and how exports of Pakistan can be improved through mobilization efforts by Pakistani embassies and trade ministry (Saleem, 2008). However, it is recommended through SMEDA SME Policy (2007) that, there should be review of prudential regulations, SME quota in annual credit plan of country, establishment of credit insurance and credit guarantee agencies, incentives for venture capital companies and other measures to support the credit financing of SMEs and create conducive business environment (Saleem, 2008). Hence, this research has covered SMEDA policies, private educational institutions' capacities and cultural tendency as core elements of entrepreneurship ecosystem in order to comprehend their impact on the entrepreneurship development in Pakistan.

\section{Research Methodology}

This study has based upon the post positivist philosophical approach, in which emphasis has been given to the quantitative side of the study. The study has used the convergent parallel mixed methods and has given equal weight to both research methods. The research process could possibly be narrated as qualitative and quantitative-QUAL + QUAN (Morse, 1991). In this type of design, few studies suggest that, the researcher simultaneously conducts the quantitative and qualitative elements in the research process, weighs both methods equally, analyzes both components independently, and then interprets the results together (Creswell \& Pablo-Clark, 2011). Hence, in this research, both methods are used at the same time and then analyzed separately and afterwards combined together in order to reach the final conclusion. However, the study has used non-probabilistic sampling because of unavailability of SME actual number and hence, the research sample has been taken through convenience method from six universities of Karachi, universities have been chosen as the presumption that, future graduates will become the potential entrepreneurs and also to find out their understanding of the current entrepreneurship ecosystem in Pakistan. The qualitative data has been collected through face-to-face interviews from nine 
individuals related to academia, incubation centers and entrepreneurs as well, as mentioned in the research design below in Figure 1. The sample size of quantitative data was $170+$ respondents, those have been chosen in order to fill the close-ended self-administered questionnaires and then, that data was analyzed through SPSS 22.0 and results were generated with hypotheses testing as well. However, the qualitative type of data has been analyzed through the trial version of Nvivo 12 . The validity and reliability of the quantitative instrument has measured through SPSS Cronbach's Alpha and the value of 0.771 has been found. The validity of the interview data has been carried out through peer review and the sharing of

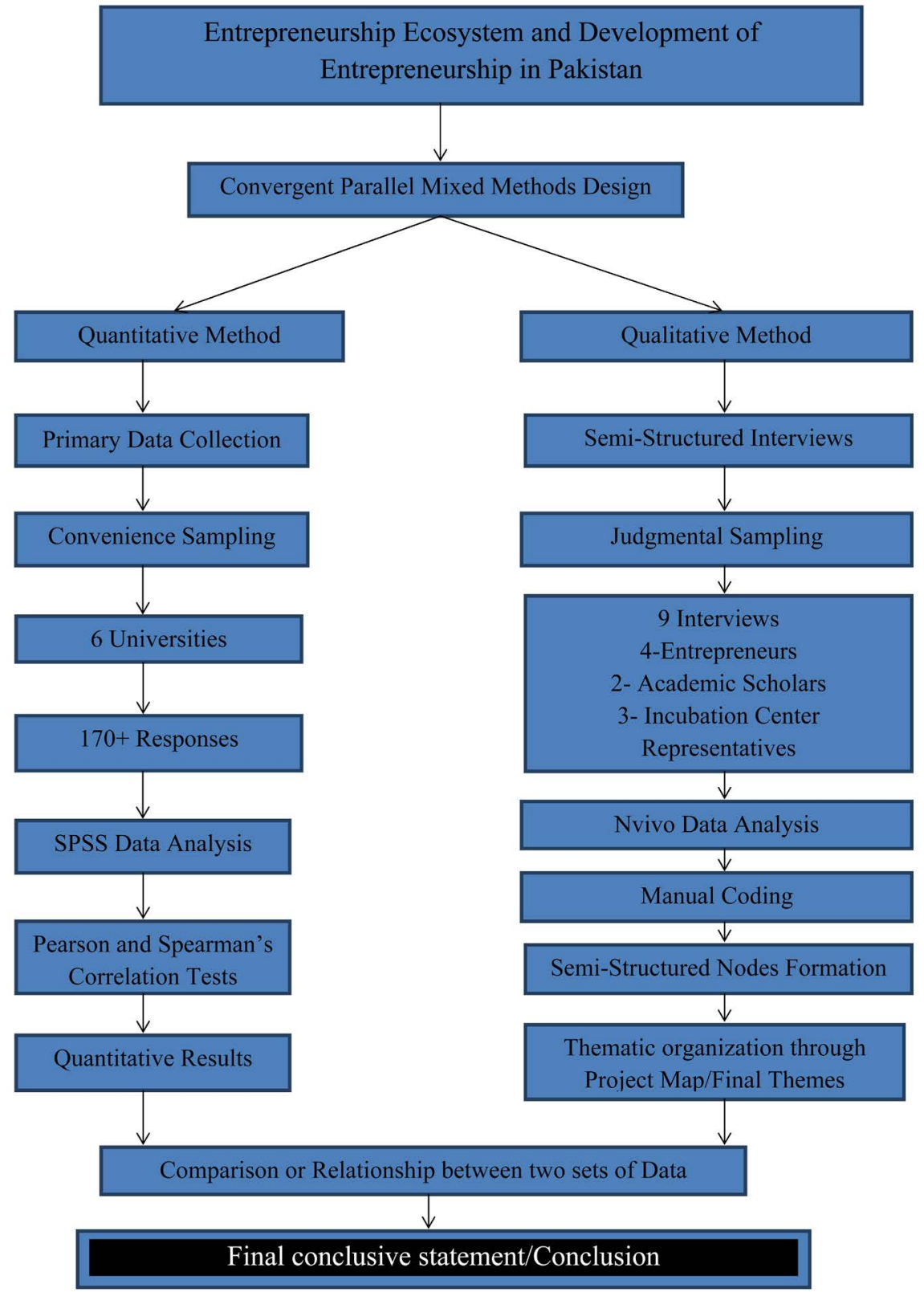

Figure 1. The research design of this study has been formulated through the inclusion of both quantitative and qualitative section. 
the final transcription and their respective part in the results and discussion section with the interviewees separately through email in order to find their feedback regarding what is being narrated against their name and all of them have approved the answers of the qualitative questions and their respective part in results and discussion section through sending the approval emails to the researcher.

\section{Research Process:}

The researcher first made the questionnaire from the related literature review and distributed that to the six universities and collected 170+ responses from the university students studying in their undergraduate final year because, the researcher would like to take into account their perception of presently available entrepreneurship ecosystem and how it can have an impact on the development of entrepreneurship in Pakistan. However, during the survey distribution and collection process, the researcher was also conducting interviews from academia, present entrepreneurs, and incubation center representatives in order to visualize the complete picture regarding the current entrepreneurship ecosystem and the possibility of adding more components into it in order to not only enhance its value but, its impact on the development of entrepreneurship in Pakistan. Therefore, after the collection of both, quantitative and qualitative data almost at the same time, the data from both versions were analyzed by using separate softwares and the results were extracted at the end. The final conclusion then depicted the results and concluded the study as a whole.

\section{Research Design (Figure 1) \\ Quantitative Data Analysis:}

It is normally observed that experimental, quasi-experimental, correlational and descriptive instruments are used in quantitative research (Holton \& Burnett, 2005). There are basically two methods of analyzing and observing the data: Descriptive and Inferential. Descriptive statistics is used in order to visualize the normal tendency of the data and the data spread and how the participants have responded to different factors and their range of answers. Inferential on the other hand, tries to find out the linear relationship between two variables and tend to accept or reject the hypotheses of the study in this regard (Kern, 2014). It is not possible to present the descriptive analysis of all the research instrument questions and hence, the only inferential analysis is added in order to approve/disapprove the hypotheses of this study.

\section{Hypothesis Testing:}

The mechanism of inferential analysis is used to find out the linear relationship between each independent and dependent variable.

\section{Hypothesis 1}

$\mathrm{H} 1=$ There is a relationship between SMEDA policies and entrepreneurship development in Pakistan (Table 1 \& Table 2)

It has been found through two tests that, there is a weak relationship between SMEDA SME policies and development of entrepreneurship, however, the 
Table 1. H1 Pearson's correlations.

\begin{tabular}{cccc}
\hline & & Independent 1 & Dependent \\
\hline \multirow{2}{*}{ Independent1 } & Pearson Correlation & 1 & $0.339^{* *}$ \\
& Sig. (2-tailed) & & 0.000 \\
& $\mathrm{~N}$ & 102 & 102 \\
Dependent & Pearson Correlation & $0.339^{* *}$ & 1 \\
& Sig. (2-tailed) & 0.000 & 102 \\
\hline
\end{tabular}

**. Correlation is significant at the 0.01 level (2-tailed).

Table 2. H1 Spearman's correlations.

\begin{tabular}{lcccc}
\hline & & & Independent 1 & Dependent \\
\hline & & & & \\
& Independent 1 & Correlation Coefficient & 1.000 & $0.252^{*}$ \\
& & Sig. (2-tailed) & $\cdot$ & 0.011 \\
Spearman's rho & & $\mathrm{N}$ & 102 & 102 \\
& & Correlation Coefficient & $0.252^{*}$ & 1.000 \\
& Dependent & Sig. (2-tailed) & 0.011 &. \\
& & $\mathrm{~N}$ & 102 & 102 \\
\hline
\end{tabular}

${ }^{* *}$. Correlation is significant at the 0.01 level (2-tailed).

relationship is significant in nature and that is why, the first hypothesis of this research is accepted.

\section{Hypothesis 2}

$\mathrm{H} 2=$ There is a significant relationship between cultural tendency and entrepreneurship development in Pakistan (Table 3 \& Table 4)

It has been found through two tests that, there is a weak relationship between Cultural tendency and development of entrepreneurship in Pakistan, however, the relationship is significant in nature and hence, the second hypothesis of this research is also accepted.

\section{Hypothesis 3}

$\mathrm{H} 3$ = There is a significant relationship between private educational institutions' capacities and entrepreneurship development in Pakistan (Table 5 \& Table 6)

It has been found through the above two tests that, there is a weak relationship between private educational institutions' capacities and development of entrepreneurship, however, the relationship is significant in nature, hence, the third hypothesis of this research is also accepted.

\section{Hypothesis 4}

$\mathrm{H} 4=$ There is a relationship between cumulative SMEDA policies, cultural tendency, private educational intuitions' capacities and entrepreneurship development in Pakistan (Table $7 \&$ Table 8) 
Table 3. H2 Pearson's correlations.

\begin{tabular}{cccc}
\hline & & Independent 2 & Dependent \\
\hline \multirow{3}{*}{ Independent 2 } & Pearson Correlation & 1 & $0.361^{* *}$ \\
& Sig. (2-tailed) & & 0.000 \\
& $\mathrm{~N}$ & 102 & 102 \\
Dependent & Pearson Correlation & $0.361^{\star *}$ & 1 \\
& Sig. (2-tailed) & 0.000 & 102 \\
\hline
\end{tabular}

**. Correlation is significant at the 0.01 level (2-tailed).

Table 4. H2 Spearman's correlations.

\begin{tabular}{|c|c|c|c|c|}
\hline & & & Independent 2 & Dependent \\
\hline \multirow{6}{*}{ Spearman's rho } & & Correlation Coefficient & 1.000 & $0.251^{\star}$ \\
\hline & Independent 2 & Sig. (2-tailed) & . & 0.011 \\
\hline & & $\mathrm{N}$ & 102 & 102 \\
\hline & & Correlation Coefficient & $0.251^{*}$ & 1.000 \\
\hline & Dependent & Sig. (2-tailed) & 0.011 & . \\
\hline & & $\mathrm{N}$ & 102 & 102 \\
\hline
\end{tabular}

*. Correlation is significant at the 0.05 level (2-tailed).

Table 5. H3 Pearson's correlations.

\begin{tabular}{cccc}
\hline & & Independent 3 & Dependent \\
\hline & Pearson Correlation & 1 & $0.266^{* *}$ \\
Independent 3 & Sig. (2-tailed) & & 0.007 \\
& $\mathrm{~N}$ & 102 & 102 \\
Dependent & Pearson Correlation & $0.266^{* *}$ & 1 \\
& Sig. (2-tailed) & 0.007 & 102 \\
\hline
\end{tabular}

**. Correlation is significant at the 0.01 level (2-tailed).

Table 6. H3 Spearman's correlations.

\begin{tabular}{lcccc}
\hline & & & Independent 3 & Dependent \\
\hline & Independent 3 & Correlation Coefficient & 1.000 & $0.198^{*}$ \\
Spearman's rho & & Sig. (2-tailed) &. & 0.046 \\
& Dependent & Correlation Coefficient & $0.198^{*}$ & 1.000 \\
& Sig. (2-tailed) & 0.046 &. \\
& & $\mathrm{~N}$ & 102 & 102 \\
\hline
\end{tabular}

*. Correlation is significant at the 0.05 level (2-tailed). 
Table 7. H4 Pearson's correlations.

\begin{tabular}{cccc}
\hline & & Dependent & Independent \\
\hline \multirow{2}{*}{ Dependent } & Pearson Correlation & 1 & $0.428^{* *}$ \\
& Sig. (2-tailed) & & 0.000 \\
& $\mathrm{~N}$ & 174 & 174 \\
Independent & Pearson Correlation & $0.428^{* *}$ & 1 \\
& Sig. (2-tailed) & 0.000 & 174 \\
\hline
\end{tabular}

**. Correlation is significant at the 0.01 level (2-tailed).

Table 8. H4 Spearman's correlations.

\begin{tabular}{lcccc}
\hline & & Dependent & Independent \\
\hline & & Correlation Coefficient & 1.000 & $0.368^{* *}$ \\
Dependent & Sig. (2-tailed) &. & 0.000 \\
Spearman's rho & & $\mathrm{N}$ & 174 & 174 \\
& & Correlation Coefficient & $0.368^{* *}$ & 1.000 \\
& Independent & Sig. (2-tailed) & 0.000 &. \\
& & $\mathrm{~N}$ & 174 & 174 \\
\hline
\end{tabular}

**. Correlation is significant at the 0.01 level (2-tailed).

This study has used two tests to find out that, there is a moderate relationship between cumulative SMEDA policies, cultural tendency, private educational intuitions capacities and entrepreneurship development in Pakistan and hence, the final hypothesis of this study is also accepted.

\section{Qualitative Data Analysis}

\section{Question No.1}

How do you define entrepreneurship ecosystem in your own terms?

In any entrepreneurial ecosystem, an entrepreneur plays a key role in the development of that ecosystem and that is why the founder of Brand mentors $\boldsymbol{M r}$. Ahmed Hassan mentioned that "Entrepreneur is the one who thinks about others and serves better than others", in the similar line of thought, Dr. Omar Javaid - the faculty member of one business school mentioned that "an entrepreneur is a person who tries to commercialize on an opportunity and innovation is not necessary for entrepreneurship, an entrepreneur is a person who finds an opportunity and builds a business around that opportunity". He further mentioned that "Innovation can play a part particularly at a later stage; however it is not a mandatory component of entrepreneurship as widely acknowledged". Moreover, he elaborated that ecosystem is the combination of "Family, education system, contacts, skills set, expert advice, investors, linkage with industry and how different business stakeholders are interacted through relationship 
management-that is the key". He further highlighted that "The contribution of entrepreneurship ecosystem is only that, it provides the alternative to those willing to do something by themselves and don't go out for a job". In addition to that, he pointed out "There is more number of startups coming out of Vietnam every year than Pakistan; however, Pakistan is far bigger in population than Vietnam". Hanna Lakhani-the co-founder of Roshni rides defined entrepreneur as "someone who tries to solve a problem innovatively" and she further mentioned that "Networking is the key for an entrepreneur and it is an important part of an entrepreneurship ecosystem and there is a bigger opportunity to utilize the networking here in Pakistan than the USA". Similarly, Dr Jawaid $A \boldsymbol{h}$ med Qureshi-the faculty member of another business school mentioned that "an entrepreneur is the one who designs new things, new technologies, find innovative and cost effective ways of doing things, the examples can be; Motorbike ambulance and Wooden bicycle in Africa and he further added that smaller businesses have more opportunities to grow because, they can invent, team up, have better ideas, new ways of doing things.". He defined ecosystem as an "Entire infrastructural support for an entrepreneur forms an entrepreneurial ecosystem". He further added that "Internal motivation is the key for the entrepreneurship, gut feeling, the way you are committing yourself to the venture".

However, Ms. Marjan Arabab from NIC Karachi highlighted that there is a government organization called "Ignite" that is creating the ecosystem by mentioning that "Ignite has the complete portal which has all the information of startups, how much money they have raised and the impact they are having on the ecosystem". She further added that "It will take time for the ecosystem to develop in such a way that the impact could be very clear and visible, the impact is not that visible". However, Nida Hasan-the founder of MOMade gave her opinion regarding ecosystem that comprises "different stakeholders, entrepreneurs, motivators for entrepreneurs, incubation centers, surroundings of an entrepreneur, Govt. agencies providing passage to youth for the development of entrepreneurial approach within them". She further added that "Best time to become entrepreneur is 15 - 30 years and entrepreneurship is built within you-someone who is internally motivated and someone who finds a need and fulfills that need, the innovation in the idea is not necessary". In the similar line of thought, Mr. Azad Ahmed-Manager (IBA CED) defined entrepreneurship ecosystem by mentioning that it "Comprises of different elements which supports entrepreneurship or that makes it easier for entrepreneurs to carry on entrepreneurial activities. He further added that entrepreneurship means "Finding a solution of a problem with sustainable business model". In addition to that $\boldsymbol{M r}$. Shahjahan Chaudhary-Project director of NIC Karachi defined entrepreneurship ecosystem as "The elements in the environment in which you do business form the ecosystem".

Question No. 2

What do you think about SMEDA policies and their role in the develop- 


\section{ment of entrepreneurship in Pakistan?}

SMEDA is the government organization that supports the small and medium enterprises through financing, feasibility reports and other related programs. While asking about the role of SMEDA most of the respondents were not so sure about its specific functionality and how it supports the idea of entrepreneurship in Pakistan. However, they had learned about its programs and had the knowledge regarding its process in general. Syed Ali Taimoor-founder of Aimdial-a legal consultancy firm in Karachi mentioned that "I don't know what SMEDA does specifically but, they support in business registration, taxation, partnership agreements and they have the online support for the potential entrepreneurs" but, he further added then "What SMEDA should be doing is to introducing entrepreneurship concept at school, college and university level and introduce compulsory entrepreneurship courses at school level-books can be introduced to teach entrepreneurship starting from class 5 onwards". Ahmed Hassan-another entrepreneur highlighted that "SMEDA, state bank and other government organizations related to business people have lengthy requirements to get finance, lengthy time to meet authorities, cumbersome procedures, they can play a good role by simplifying procedures, providing easy access to higher authorities, removing bureaucratic trap". He further added "If SMEDA plays a $10 \%$ role; the entrepreneurship can increase tremendously in the country". $\mathrm{He}$ also ended by pointing out that "SMEDA should teach: How to sell a product because that is the biggest hurdle for any new entrepreneur". Mr. Azad Ahmed-Manager (IBA CED) mentioned that "SMEDA business plans and models are based on causal model and that is not applicable in the context of Pakistan." He further added that "SMEDA needs to mould its existing model and can introduce a new way of making a business plan and that is business model canvas. However, SMEDA is trying very hard, working very hard to promote small business and to support small and medium enterprises". Similar kind of idea is propagated by Dr Jawaid Ahmed Qureshi-the faculty member of one business school that "SMEDA focus is basically on causal model of entrepreneurship not on effectual model of entrepreneurship". He specifically said that it provides "feasibility studies, knowledge regarding business plans, a lot of guidance but following causation model". He emphasized that "Effectuation model should be followed and entrepreneurship will increase if SMEDA start following effectuation model, However, SMEDA can do training on both causation and effectuation both not only causation as now". Dr. Omar Javaid-the faculty member of one business school also gave the similar thoughts by favoring that "If SMEDA follows the effectuation based model then, the number of entrepreneurs can increase through the help of SMEDA otherwise, and it would be difficult". He further mentioned that "The support provided by SMEDA to the new entrepreneur is actually questionable because, they suggest you to make a business plan; they provide you the training regarding how to make the business plan. Even, if that individual makes the business plan and eventually somehow gets the money 
from the bank, still, his success is in question because, he/she doesn't know how to execute business or don't have the relevant experience of marketing and selling that product or service. The money can eventually be lost and he/she can become the defaulter of the bank".

Hanna Lakhani-the co-founder of Roshni rides said that "It is hard to connect to Govt. officials and I don't know much about SMEDA". But she added that "So many great startups and great ideas are out there are not supported either financially or in terms of guidance or mentorship, SMEDA should focus on bringing more opportunities to new startups by providing them more money, more guidance, even proper workshops or classes in order to learn and grow, proper guidance and funding are necessary for new entrepreneurs". Ms. Marjan $A r a b a b$ from NIC Karachi mentioned that "SMEDA focuses on Small and medium businesses not startups, they provide guidance regarding business sustainability and running your business in a good way". Nida Hasan-the founder of MOMade-gave her opinion by saying that "SMEDA has the definite role but, it doesn't have the exposure". She further elaborated that "There must be some platform to an individual who thinks realistically in order to fulfill the needs of his/her surroundings and that platform supports his/her idea and helps him/her in its execution". She goes on the conversation by saying that "Major hindrance for young entrepreneurs is financing especially those following causal model, but, if you have an idea and you have implemented it through effectuation model, then, if you try hard, you find people who support you eventually and If Govt supports through easy loans to those either following causal model or effectuation model, the entrepreneurship will increase because, Pakistan has the potential but, exposure is needed". Mr. Shahjahan Chaudhary-Project director of NIC Karachi mentioned that "I don't know much what SMEDA does, but, I do find some feasibility studies at their website".

Question No. 3:

What is your opinion about the cultural tendency; does our culture support/discourage the idea of entrepreneurship in Pakistan?

Culture does influence on the actions of the individuals as while asking this question from Mr. Shahjahan Chaudhary-he mentioned that "Culture supports the development of the nation by either supporting or discouraging some activities, like in some cultures, parents instruct their children of $10-12$ that, you are elder enough now so, you should do some work. But, in our culture, parents instruct their children of $10-12$ years to do the study first and focus on your exams, not the work". He further emphasized that "Culture infuses different beliefs into their children and youths and outcome of those beliefs is the individualistic actions, for example, if the belief is that, you must do a job, then most people will go for a job, but if the belief does the business like in Memon and Shaikh community, their children and youths do the business, however, majority belief in our culture is to do the job". Ahmed Hassan-an entrepreneur highlighted that "Currently, only $4 \%$ to $5 \%$ of our society is supporting en- 
trepreneurship and Success for today's individual is do MBA and get job and that can be changed, if parents support entrepreneurship endeavor and they guide their children to do business at small risk". Syed Ali Taimoor-another entrepreneur augmented that "Parents think in a traditional way and culture discourages entrepreneurship as a whole and more graduates are willing to do job than business". He further added that "But there is a change being seen and now, young graduates are moving slowly into the field of entrepreneurship". But, he then focused upon the reason behind that trend of doing job after graduation than business and the trend is based upon social structure of Pakistan "Middle class individual needs financial support to do business and it is not provided usually by the family, so if you are a middle class individual, $80 \%-90 \%$ chance is that, you are going to do job and earn money, the support that the family doesn't provide like letting someone to experiment with their idea for 2 3 years and start your own organization or start up and don't pressurize that person to do the job because, if that individual fails, he/she can return to the job market". But in the case of upper class family "They have two options, first is that the individual and his/her knows in advance that, what the individual is going to do next, for example, if an individual in upper class family wants to become a painter or an artist, the family supports that decision and the second option is that, he/she can join the existing business because, upper class is usually regarded as business class and if an individual chooses a third option and starts his/her own business, the family do support that individual partially but, that is not seen in lower or middle class families".

However, Mr Azad Ahmed-Manager (IBA CED) noted the different reason for doing job than business and that is "Because, Pakistan is a commonwealth country and commonwealth countries are mostly ruled for decades by some ruler, we had that mentality in majority of population mind that one should have a career in any established company or public sector and that is the big problem". He further mentioned that "Students have more peer pressure from family, friends to get a good job and get a good degree in order to have stable monthly income" Then he started to compare US and Pakistan entrepreneurship ecosystem by saying that "US has the strongest entrepreneurial ecosystem in the world and that is because, in the USA, the young graduate is not responsible to support his/her family after graduation but in the Pakistani family system, our culture expectation is that, after getting education, he/she would start supporting their families, but when you want to become an entrepreneur after completing your studies, you need to start investing in terms of time and money into your idea until that idea becomes successful, that is why, the gap between idea generation and idea realization creates pressure (in terms of time and monetary value) on those wanted to become entrepreneur after graduation in Pakistan".

Dr. Omar Javaid - the faculty member of one business school gave the similar thoughts by saying that "Social structure of USA or culture is pro-entrepreneurship and it supports the persistence and investment on a single idea until it matures 
and that is regarded as good while in Pakistan, most of the entrepreneurs or successful entrepreneurs often get distracted from their core business or idea and try to do something else after a short time". He further exemplify that "if you have any idea and you are working on that idea, meanwhile, your life partner runs the home, until that idea is matured and that trend is not seen in Pakistan and it is not possible in our present cultural system". However, "There are some communities in Pakistan like Memon, Delhiwala and Chinioti communities (Just few examples) those are known for their entrepreneurial orientation". He further added "Memon community child once he is aged around 12 - 15 years, he start getting exposure of family business in his childhood and that I found while speaking in NED University that there was one memon student in that class having retail business experience of 6 years as compared to his friends having zero experience". He further gave the notion that "Family is the major influencer in children career choice in Pakistan as compared to someone living in Europe or America, the influence is not much there, but in Pakistan, family mainly decides which field he/she is going to enter, what kind of education he/she is going to get, whom he/she is going to marry, all those decisions are heavily influenced by family members, until and unless family supports, nothing is possible". But another entrepreneur-Hanna Lakhani pointed out that "Parents want their children to do a stable job everywhere whether in USA or Pakistan but, millennial generation are much more willing to take risk, they want to do job, that is impactful, making a difference, the younger generation wants to make a change in the world and the old generation should realize that fact". However, Dr Jawaid Ahmed Qureshi-a business faculty member stressed upon that "Culture considers businessmen or entrepreneurs are same as small business owners, Hence individuals in Pakistan prefer jobs especially the government ones like military or judiciary jobs or high status-quo jobs because, there is a general perception in the culture that, those getting government jobs can have social contacts, money and power, but, however, environment or culture is slightly changing". Ms. Marjan Arabab mentioned that "Culture supports the entrepreneurship endeavor, the parents and community supports it but it varies from people to people, family to family and it depends on the social class structure like lower middle class, middle class and upper class. Middle class families usually support their members to become entrepreneurs than lower middle class" Hence, "There are many startups in NIC those belong to middle class families". Nida Hasan from MOMade gave the idea that "Job is preferred over doing business because of fixed income and low risk and risk taking is inhibited in the society". She further added that "Culture and economic condition is not supportive for entrepreneurship, and it is difficult to carry out one single idea in Pakistani culture, because, persistence needs patience, lack of patience is usually observed in youth of Pakistan". Moreover, she emphasized that "Change in parental mindset can lead to changing child's mindset. There must be some working on family level and parents should not force their career choice on their 
children, Parents should be guided like; there must be at least one entrepreneur in your family, but the problem is, even after getting independence 70 years before, the mind of a slave is still there; people can come out from this mindset through their surroundings or their internal motivation-only in some rare cases".

Question No. 4

What do you think regarding the private educational institution's capacities (like university) and its contribution in the development of entrepreneurship in Pakistan?

Education is the core element of any progressive nation and Pakistan is not different in this regard but, the importance given to the field of entrepreneurship is a new phenomenon as Syed Ali Taimoor-an entrepreneurship mentioned in the interview that "There is a late awareness regarding entrepreneurship and there is also not much information provided by the universities regarding entrepreneurship in Pakistan". He further added "Universities are teaching outdated courses, outdated materials which are not relevant today" While talking about the foundation, he mentioned "Entrepreneurship foundation should be laid in schools like from class 5 or 6 , and over there, the student should be taught about entrepreneurship, Career choice should include entrepreneurship as a choice at primary or secondary level and the auxiliary skills should be provided in class 6 or class 7". Ms. Hanna Lakhani-another entrepreneur pointed out that "Out of box thinking is not promoted at school level and thinking is basically shaped at school level, development of the mind happens at elementary and mid-school level and there should be some working at that level". She further mentioned while comparing USA education system with Pakistan that "There should be more courses on entrepreneurship or even majors, there should be more awareness to the students regarding the entrepreneurship courses or majors, for example, universities in the USA has other options except the traditional majors like finance, accounting, and marketing, they do introduce new options like fashion, entrepreneurship or green supply chain either as major or minor, Pakistani education system should have the same because, those courses give exposure to the different fields as, they can provide you the basics of the field for one wishes to indulge in the future". She added that "Entrepreneurship clubs at university level are beneficial because, those clubs provide the taste of what entrepreneurship is; they provide you the exposure of the field". However, Dr Jawaid Ahmed Qureshi-an academic introduced firstly the two types of entrepreneurship model, causal and effectual and then he mentioned that "Traditional books being used in universities in Pakistan don't include effectuation model but, even in the USA, the effectuation model is not taught, they focus on innovative ways that can way to millions, but, the current curricula in business schools on entrepreneurship cover a lot of things like managerial skills, particular entrepreneurial skills". He further elaborated by saying that "IBA Karachi has got an edge because they are using the effectuation model in their trainings and courses, they are organizing entrepreneurship educator symposiums, training faculty 
from all fields and from all across the country, professors from all fields are attending the trainings, hence, the current business faculty now starts differentiating between traditional and entrepreneurship model due to the IBA Karachi initiatives". He added then "Nowadays, universities in Pakistan are also introducing specialized courses on entrepreneurship and somehow, every educational institution is supporting entrepreneurial activities because; it is a requirement of HEC (Higher Education Commission, Pakistan) and National Business Education Accreditation Council (NBEAC) also provide their support for the entrepreneurship endeavour". He lastly included that "IBA Karachi is also the first mover in children entrepreneurship program, school children of 5th to 10th grade are invited in those programs". However, Ahmed Hassan-highlighted that "Teachers in universities emphasize to become corporate slaves during MBA programs (follow boss instructions)" But then he also mentioned that "Universities do play a vital role in promoting entrepreneurship as IBA CIE (Certificate in entrepreneurship program) gave me confidence; they just pushed me to do business as I was quite afraid of doing business". He further added then "Universities must collaborate with emerging entrepreneurs, those can share their experiences with the students and career choice counseling is also necessary at university level".

Nida Hasan from MOMade also gave her opinion while saying that "I am also a graduate of Iqra University and IBA CED entrepreneurship program and Effectuation model is partially followed over there". She further included that "In IBA CED-we start from the effectuation model but then, the causal model is also introduced and in my opinion, effectual and causal model, both are necessary to move forward because, causal model is necessary to move forward as; there is an end to everything". While highlighting the role of education in promoting entrepreneurship, she narrated that "Teachers, management and parents play a vital role in the success of students and they should conduct some tests that highlight and polish the inherent talent of any student rather than suppressing that talent (e.g. Personality test, IQ test, EQ test, MBTI test)". She then included "Universities are just teaching entrepreneurship, however, they do have the capacity to promote and implement entrepreneurship but unfortunately, they don't work on it, $t$ they don't try to provide a platform to implement pilot projects; they mainly focus on developing business idea through causal model. Hence, they usually teach their students to follow causal model steps but unfortunately, they all are Google based". She lastly added that "Entrepreneurship should be taught at school level and career counseling should be provided there as well and there are some schools in Karachi providing career counseling sessions to their students".

However, a new dimension to the phenomenon was given by Mr. Shahjahan Chaudhary-by arguing that "The University is a learning organization where students and teachers meet, where they explore new things and understand the world and it is not the university objective to produce entrepreneurs but, it has 
the broader scope of producing engineers, artists, philosophers, scientists and even entrepreneurs in the society as well". He further mentioned that "Engineers, artists, philosophers, scientists and also bureaucrats have the potential to become entrepreneurs because; it is actually a process of value creation". $\mathrm{He}$ lastly added that "Entrepreneurship is just one element in the whole education system but, if universities teach more courses on entrepreneurship, produce more entrepreneurship clubs or incubation centers, the entrepreneurship will increase by that means because then, it will create more awareness among the masses, and those efforts will have an outcome and by the way, the awareness can be created by teaching entrepreneurship at school level as well".

Mr Azad Ahmed-gave his opinion regarding the two types of entrepreneurship models-Causal and Effectual and then defined the effectual model that, "It is 360 opposite to causal model and it is to create an effect with whatever resources you have like Family, friends, your network, and your skills". Then, he added that "IBA is teaching effectual entrepreneurship model in its entrepreneurship courses like (CIE) but, IBA is also teaching entrepreneurship courses at undergraduate and graduate levels". He further elaborated by saying that "Private educational institutions do have the potential, but, the mindset of management and faculty teaching entrepreneurship in the private educational institutions needed to be aligned with the local culture of Pakistan, unfortunately, we have the tendency to copy the things from outside and that is why, the majority of public and private educational institution in Pakistan teach causal model of entrepreneurship and that is not beneficial as in the case of startups in Pakistan, That is why, the mindset of management of those institutes and the faculty teaching entrepreneurship should be changed in order for private educational institution to play a very important role". He then highlighted that "IBA has started technology and kids' entrepreneurship programs and more importantly 'National Entrepreneurship Program' in collaboration with multiple universities in varied areas of Pakistan (e.g. Faisalabad, Gujranwala, Hyderabad) and we are also trying our best to expand in other parts of the country in order to build an entrepreneurial mindset, that can produce an impact". He finalized by arguing that "It is right that business students don't have particular technical skills and they need to work on building those skills but, entrepreneurship doesn't happen with the single individual, even the most successful ventures are started by a team of 3 to 4 people and they all come from different backgrounds like finance, marketing and others".

Dr. Omar Javaid-mentioned that "Faculty in general is not providing the proper guidance to their students and don't encourage them to do something different or think out of box, it doesn't help them to create the vision for themselves". He then added that "Our education system is based on bureaucratic system and entrepreneurship mindset is 180 degree opposite to bureaucratic mindset, Bureaucracy wants control, stability, and entrepreneurship wants to do experimentation, try new stuff, and make mistakes". He then elaborated that "Fac- 
ulty can play a role in the formation of a vision for their students and can introduce entrepreneurship as an alternative in their career choice. University faculty can produce the entrepreneurship mindset through interactive teaching and highlighting the importance of entrepreneurship for young adults, mindset can be developed through practical examples of job oriented people, who have become successful entrepreneurs, through classroom teaching in universities. Unfortunately, not all faculty members are promoting the idea of entrepreneurship, what they promote is to get a job after graduation. Job orientation is mostly provided by the faculty through their constant emphasis to get a good job after graduation. Only some individuals take a different route and have a motivation to start their own business". He then highlighted a problem by saying that "There is a problem with BBA students that, they don't have any skills to produce any particular product, that is why, what they can mostly do with their existing academic skills is to do distribution based business, developing e-commerce website at the utmost, but $70 \%-80 \%$ of them are selling T-shirts, clothing, accessories and opening their own food outlets. There is a lack of marketing, accounting and especially relationship management skills and an entrepreneur should have those skills". He then added that "The people's management or relationship management is very crucial for any successful business, but those skills are not taught at any level in our education system".

\section{Question No. 5}

In your opinion, if we devise more entrepreneur friendly SMEDA policies, conductive cultural environment and appropriate private educational institution's capacities, would the amalgamation of these all three, contribute into the development of entrepreneurship in Pakistan?

While answering this question, almost all of the respondents were agreed on the notion that, these three components will increase the number of entrepreneurs in Pakistan. Syed Ali Taimoor-an entrepreneur mentioned that "By having better SMEDA policies, supportive culture and universities or schools supporting entrepreneurship, the number of entrepreneur or culture of entrepreneurship will improve". He further added that "Schools or colleges should have the same culture of visiting faculty as in the case of universities and they should invite successful entrepreneurs to give lectures that will increase the exposure". He finalized by saying that "Entrepreneurship should be started at the basic level, it should be embedded in the culture or in the environment". Ahmed Hassan-an entrepreneur highlighted that "Combination of all these variables will increase the number of entrepreneurs like from currently 5000 to 15,000 or even to 20,000 , the ratio will increase, GDP will increase by that way as well, because if the entrepreneurship increases in Pakistan, the unemployment ratio will decrease, Net national income (NNI) will increase because some entrepreneur will export as well. New entrepreneurs will create more jobs and an individual will be shifted to giving side of the economy rather than taking side. He finalized by saying that "Pakistan image will be softer because of increasing entrepre- 
neurship at the international level in the future".

Moreover, Mr Azad Ahmed-IBA CED Manager emphasized that "Yes, obviously, better SMEDA policies, supportive culture and universities supporting entrepreneurship, by that means, the entrepreneurship will increase, however, we don't have any empirical evidence regarding that, but, as common sense suggests, improvement in these factors can promote entrepreneurship positively in the country". He finalized by saying that "It is observed that, big multinational companies are not investing in Pakistan so, promoting entrepreneurship can solve economic problems of Pakistan like they can create jobs, reducing unemployment rate and solving the local issues of Pakistan". Ms. Hanna Lakhani-another entrepreneur narrated that "All three component, better SMEDA policies, supportive culture and universities promoting entrepreneurship will increase the number of entrepreneurs in Pakistan because, if every stakeholder is supportive in the person's life, then the impact will eventually come.

For example: if an elementary or middle school is focusing on entrepreneurship mindset, teaching how to think out of box, how to think like an entrepreneur to their students and if as a whole, an individual is getting support from their educational system, family, government, college or university, by that way, the entrepreurship will increase, but, SMEDA can also promote entrepreneurship; it can contribute in creating entrepreneurial mindset in Pakistan at the end of the day". Dr Jawaid Ahmed Qureshi-an academic also promulgated the similar idea by saying that "Better SMEDA policies, supportive culture and universities promoting entrepreneurship will increase the number of entrepreneurs in Pakistan because, Culture is gradually changing and SMEDA should do training on effectuation as well, It can deliver training on both causation and effectuation models of entrepreneurship not only on causation as of now". Mr. Shahjahan Chaudhary-Project director of NIC Karachi gave his thoughts by saying that "If all the things become better like we have better SMEDA policies, supportive culture and universities promoting entrepreneurship, eventually the number of entrepreneurs will increase in Pakistan" but, he further elaborated that "Whenever you do something, the basic objective is to give something or to take something, If you add value, and the focus is on giving rather than taking, then the outcome of that action is revenue generation, if the entrepreneurship is focused on giving, the society becomes better, otherwise, the entrepreneur can be involved in malicious intentions (telling lies, cheating) where the prime goal is earning by hook or crook rather than giving so, the entrepreneurship should focus on mutual benefit". He also mentioned that "We should teach entrepreneurship at school level as well". Moreover, Dr. Omar Javaid suggested that "If family and education system both support the entrepreneurship, then there would be good number of entrepreneurs in the future" $\mathrm{He}$ further added that "However, there is a link between entrepreneurship ecosystem and development of entrepreneurship". Finally, Nida Hasan shared her thoughts by saying that "There should be coordination between government institutions (SMEDA and 
others etc.), legal institutions (FBR etc.), universities and industries in order to promote entrepreneurship because these all are integrated" She further mentioned that "There should a proper system so that an entrepreneur easily cope up with all these matters whether it is legal or financial or it is related to one's idea, there should be counselors or mentors as well, who can do mentorship at initial stages and then, they give chance to potential entrepreneurs to run their own pilot project".

\section{Question No. 6}

How do you perceive the impact of entrepreneurship ecosystem on the development of entrepreneurship in Pakistan?

Entrepreneurship is well defined and the concept was elaborated by different interview participants and almost all mentioned that it is formed through the interaction of multiple stakeholders like entrepreneurs, investors, suppliers, experts, government agencies, venture capital firms, incubation centers and etc. Nida Hasan-an entrepreneur mentioned that it comprises of "Different stakeholders, entrepreneur itself, motivators for entrepreneurs, incubation centers and government agencies working on the youth". She further mentioned that "Surrounding is the incubation center for the entrepreneur". So, if the ecosystem consists of different stakeholders, incubation centers and government do play a key role in the formation of that ecosystem and that eventually have an impact on the development of entrepreneurship despite culture tendency and other relevant factors as incubetee herself incubates her idea in that particular ecosystem. Interestingly, in the similar line of thought Ahmed Hassan-another entrepreneur shed light by saying that "Incubation centers are going extra mile, doing very well in promoting entrepreneurship, they are providing platform on national and international level, they provide business place, business leads, provide business strategies". He further added that "Universities should establish incubation centers in their existing buildings in order to save cost of establishing new incubation centers and SMEDA can support this endeavour by providing easy TRFs (Terms of references) for establishing incubation centers in universities". However, Syed Ali Taimoor-an entrepreneur mentioned that "There are $80 \%$ entrepreneurs in some incubation center are IT professionals". In the similar line of thought Mr Azad Ahmed-augmented that "if any entrepreneur is starting some technology based business, he/she needs support in the areas of finance, accounting, taxation, and marketing and if small ventures provide that business support, the entrepreneurial ecosystem becomes better by that way as in the example of Stallion deliveries and Createch, they both were incubated in our incubation center so, when Stallion services had expanded, they need an ERP system and that was provided by Createch-our another startup". He further added that "Brand mentors startup was also created by one of our entrepreneurship program graduate that facilitates in legal, regulatory, taxation and registration process". He finalized by saying that "The aim of incubator is to provide enabling environment and some sort of entrepreneurial ecosystem for the 
aspiring entrepreneurs to build their ideas or to convert their ideas to sustainable business model and IBA do facilitate in this regard". However, Dr. Omar Javaid-the faculty member contrasted with the idea by mentioning that "Carl Schramm (author of Burn the Business Plan) has emphasized in his book that, despite in the USA more and more universities are offering entrepreneurship courses, the culture of startup competitions, incubation centers and other entrepreurship programs are on the rise but, interestingly, the number and percentage of entrepreneurs is decreasing in the USA. Hence, there is some kind of systemic fallacy in the system". While Ms. Hanna Lakhani-highlighted that "Incubation centers in the universities are amazing and beneficial as Roshni rides also got support from the Nest I/O (a private incubation center)". Dr Jawaid Ahmed Qureshi-an academic also supports the idea by saying that "It is supportive, it is working and providing infrastructure to the entrepreneurs". But he also said that "Especially useful in engineering universities, engineers have produced new technologies with their professors and afterwards commercializing them". Mr. Shahjahan Chaudhary-also added that "Incubation centers are actually the community centers and they provide the space where entrepreneurs, engineers, designers can meet and achieve their collective objective, they connect people to opportunities, they provide a role of matchmaking, connecting, networking and we should also make more incubation centers in interior Sindh, Interior Punjab, even though, we should make more publicly available community centers, and those centers also focus on entrepreneurship as well”. While taking regarding the role of different stakeholders and their impact on the development of entrepreneurship with one of the entrepreneurs-Syed Ali Taimoor-he mentioned the role of government by saying that "Policies should approach at school or at gross root level and we need to introduce compulsory entrepreneurship course at that level in order to develop entrepreneurship". Similarly, $\boldsymbol{M r}$ Azad Ahmed-highlighted that "The role of government is very important because once the startup is growing, it faces so many issues like taxation and other regulatory problems, they impose so many challenging situation that it becomes very difficult for any startup to expand and they eventually are demotivated. The startups those faced such situation have shared their experiences especially how the FBR creates hurdles in their way or problems for them. There should be national policy to support the startups in taxation especially and in other regulatory matters as well. It is not possible to comply with regulatory framework and policies those aimed at large companies, hence, the government should take into account the challenges and point of views of startups while formulating the policies and regulatory framework those aimed at facilitating startups" that can increase the number of startups in the country and it can also encourage the established startups to become medium or large size in the future. In the similar line of thought, Dr. Omar Javaid-the faculty member mentioned that "Business registration process is not so easy; you can't do it by yourself, but if you have done it 2 to 4 times, then it becomes easy. However, taxation process 
particularly is very difficult and you have to take advice from any lawyer. But, even if the government facilitates in business registration and taxation process, existing entrepreneurs can get benefit from it but, it will not increase the number of entrepreneurs in Pakistan. However, the legal process of registering a business should be easier as compared to the process available today and the easier process will encourage those entrepreneurs who are still unregistered". He further added that "The patent registration and copyright process should be easier in Pakistan as compared to today's process". The academic finally concluded by saying that "State's primary role is to provide security to one's life and property. If people feel that their investments will be secured, the govt. and state institutions will facilitate and will not create unnecessary bureaucratic hurdles, in that case, the entrepreneurship will naturally flourish".

Ms. Hanna Lakhani-while asking about legal formalities pointed out that "it takes a long time to open a bank account and transferring money from abroad if someone is coming from abroad and starting his/her own new venture like Roshni Rides. The procedure involves stack of paper work, a stack of finger prints in order to open a bank account and the process is frustrating for new entrepreneurs, This is the basic or prime step to start any new startup and it is quite discouraging, new entrepreneurs can be discouraged at this step and don't move further. NTN process is also not that simple for new entrepreneur and registering a company is not that easy and frustrating. There is also not much clarity regarding what rules and regulations to follow by a new entrepreneur, Guidance must be provided regarding the rules and regulations to the new entrepreneur. Govt: can organize workshops or someone who can guide the new entrepreneurs would be good. She finally mentioned that "Any central building or advisory can be established in order to provide the guidance and support to the new entrepreneurs and that can increase the number of entrepreneurs in $\mathrm{Pa}$ kistan".

However, Dr Jawaid Ahmed Qureshi-an academic gave the mixed opinion regarding the role of government by saying that "Minimum salary requirement is a hurdle for small entrepreneurs-especially when they are smaller in their sales turnover, the taxation mechanism is quite complex, there is red tape involved and financing from banks is also big trouble, they are harsh to the young entrepreneur, however, registration process is not that much difficult". Although, Ms. Marjan Arabab from NIC Karachi shared the similar thoughts regarding taxation that "Any start-up when it becomes the legal taxpayer, there are a lot of taxes needed to be paid to the government and hence, the startup become restraint to remain small rather than grow in the entrepreneurship ecosystem". While Nida Hasan-an entrepreneur gave a different direction by saying that "Entrepreneurship can increase if there is a system in place that support the new entrepreneur either through financial support, legal support or support in implementation of their idea through counselors or mentors-who can initially guide an entrepreneur at their initial stage or at least help them in order to run 
their pilot project". Lastly Mr. Shahjahan Chaudhary-shared his opinion regarding the role of government in the development of entrepreneurship in Pakistan by saying that "Government policies need to change a lot, if the Govt wants to grow small business and entrepreneurship in the country". As in my opinion, the main and prime benefit of small businesses, that they can employ at least 10 to 20 people but, if someone wants to open a small business by following legal procedures, the job is quite cumbersome. That entrepreneur needs to pay and think about taxes, like sales tax, withholding tax, banking transaction tax, the percentage is too big for small businesses, there should not be heavy taxes on small business, the taxes are fine, if the business becomes big enough or the revenue generation is more than 10 million. But, in reality, when you start the business, it usually takes time to reach even at the breakeven point, so, there must be tax exemption for some initial years to the new businesses until they are established or flourished because the small business owners are doing business initially at the loss and at the same time, he/she has to pay taxes. Govt. should not ask them to pay taxes from the day 1 of their business and there must be tax holidays for initial 2 to 3 years for new startups. He further added that "Registration process is not smooth for any new person as well, he/she can't do it by himself/herself, any new person needs the lawyer to register the business (incubation center connect their startups with the lawyer). However, it should be as smooth as opening a Gmail or Hotmail account or filling any online form, like your CNIC provides the basic information about you and if the company name is available, it should be opened immediately". He finalized by pointing out that "Entrepreneurship will increase in Pakistan, if Govt. streamlines at least three basic processes namely, company registration process, bank account opening process and taxation process for new startups".

\section{Analysis of Qualitative Responses}

This research was conducted in order to elaborate the concept of entrepreneurship ecosystem and how it can have an influence on the development of entrepreneurship in Pakistan. The study was conducted under the influence of entrepreneurship ecosystem model created by Daniel Isenberg in 2011 through his Babson entrepreneurship ecosystem project during which, he created the model consists of mainly six domains and those are: favourable culture, workable policies, financial availability, capable human resource, enabled market mechanism and subsequently a range of institutional support (Isenberg, 2011). That is why, when the questions being asked regarding the domains taken by this study under its investigation, one of the respondents (Dr Jawaid Ahmed Qureshi) mentioned regarding entrepreneurship ecosystem as "Entire infrastructural support for an entrepreneur forms an entrepreneurial ecosystem". However, entrepreneurship was defined by another respondent (Mr. Azad Ahmed) as "Finding solution of a problem with sustainable business model". Similarly, Mason \& Brown (2014) mentioned about entrepreneurial actors in the ecosystem includ- 
ing entrepreneurial organizations, government organizations, venture capital firms, large businesses, universities, incubation centers and business advisory and legal consulting firms. When the discussion with the different interviewees was carried out, initially culture, educational system and legal framework remained at the core of the discourse. Hence, it was mentioned by one of the respondents (Hanna Lakhani) while asking regarding SMEDA policies, she mentioned that "So many great startups and great ideas are out there are not supported either financially or in terms of guidance or mentorship, SMEDA should focus on bringing more opportunities to new startups by providing them more money, more guidance, even proper workshops or classes in order to learn and grow, proper guidance and funding are necessary for new entrepreneurs". Almost all respondents agreed in one way or another that, effectuation model of entrepreneurship is a better fit in the context of Pakistan, hence one of the respondents (Dr. Omar Javaid) mentioned then "If SMEDA follows the effectuation based model then the number of entrepreneurs can increase through the help of SMEDA otherwise, it is not possible". The similar suggestion was given by two other respondents like Dr. Jawaid Ahmed Qureshi and Mr. Azad Ahmed. Hence, Sarasvathy (2008) mentioned that the effectual entrepreneur is different from the one following causal model because, that entrepreneur is not just expert in his/her domain but willing to take risk, show spontaneity and possess the skills of situational leadership. While asking regarding the role of culture in the development of entrepreneurship one of the respondents (Nida Hasan) mentioned "Job is preferred over doing business because of fixed income and low risk and risk taking is inhibited in the society, culture is not supportive for entrepreneurship, and it is difficult to carry out one single idea in Pakistani culture, because, persistence needs patience, lack of patience is usually observed in youth of Pakistan". The idea of persistence and lack of patience was also mentioned by one of the respondents (Dr. Omar Javaid). However, one of the respondents (Ahmed Hassan) highlighted that "Currently, only $4 \%$ to $5 \%$ of our society is supporting entrepreneurship and success for today's individual is do MBA and get job and that can be changed, if parents support entrepreneurship endeavor guide their children to do business at small risk". Another respondent (Syed Ali Taimoor) shared the similar notion that "Parents think in a traditional way and culture discourages entrepreneurship as a whole and more graduates are willing to do job than business". The arguments regarding culture were supported by the literature, culture does play a critical role in the entrepreurship development (Abzari \& Safari, 2010). Furthermore, while asking the contribution of private educational institutions in the development of entrepreneurship, one of the respondents (Syed Ali Taimoor) mentioned "Universities are teaching outdated courses, outdated materials which are not relevant today, Entrepreneurship foundation should be laid in schools like from class 5 or 6 , and over there, the student should be taught about entrepreneurship, entrepreneurship should be included as a career choice at primary or secondary level and the aux- 
iliary skills should be provided in class 6 or class 7". While taking about auxiliary skills one of the respondents (Mr. Azad Ahmed) mentioned the USA high school curriculum by saying that "it is taught in their high school curriculum like how to cut wood, iron, how to fix wires, the entrepreneurship mindset is developed at that level and people are comfortable doing their own work but, the trend is totally different here". Another respondent (Ms Hanna Lakhani) augmented the idea "Out of box thinking is not promoted at school level and thinking is basically shaped at school level, development of the mind happens at elementary and mid-school level and there should be some working at that level". While asking the same to the respondent from academia (Dr. Jawaid Ahmed Qureshi) the respondent mentioned "Traditional books being used in universities in Pakistan don't include effectuation model but, even in the USA, the effectuation model is not taught, but, however, the current curricula in business schools on entrepreneurship cover a lot of things like managerial skills, particular entrepreneurial skills". The notion was somehow in contrast with another respondent point of view "Teachers in universities emphasize to become corporate slaves during MBA programs (follow boss instructions), but universities do play a vital role in promoting entrepreneurship as IBA CIE (Certificate in entrepreneurship program) gave me the confidence to do business". Another respondent (Nida Hasan) added "Teachers, management and parents play a vital role in the success of students and they should conduct some tests that highlight and polish the inherent talent of any student rather than suppressing that talent (e.g. Personality test, IQ test, EQ test, MBTI test)". Another academia (Dr. Omar Javaid) while asking the same added "Faculty is not providing the proper guidance to their students and don't encourage them to do something different or think out of box, it doesn't help them to create the vision for themselves". The narrative build by the respondents was somehow confirmed by the study of Eze (2011) in which they mentioned that; entrepreneurship mindset is influenced mainly by two institutions: Family and education. Entrepreneurship education has got the attention in formal institutions recently because it can reduce unemployment and poverty as well, as the unemployed can start their own business and generate wealth through different business activities.

\section{Discussion}

Although, when the quantitative side of this study is converged with the qualitative data and investigated, it was found that $66 \%$ of the respondents, those filled the self-administrated questionnaire of the study were agreed from $40 \%-80 \%$ regarding the collective role of SMEDA policies, cultural tendency and private educational institutions' capacities in promoting and developing entrepreneurship in Pakistan. Although, when the question being asked regarding the collective role of the three research variables from the interviewers, most of them agreed as one of the interview respondent (Syed Ali Taimoor) mentioned "By having better SMEDA policies, supportive culture and universities or schools 
supporting entrepreneurship, the number of entrepreneur or culture of entrepreneurship will improve". Another interview respondent highlighted "Combination of all these variables will increase the number of entrepreneurs like from currently 5000 to 15,000 or even to 20,000 , the ratio will increase, GDP will increase by that way as well, because if the entrepreneurship increases in Pakistan, the unemployment ratio will decrease, Net national income (NNI) will increase because some of them will export as well". However, one of the interview respondents (Dr. Omar Javaid) from academia mentioned "If family and education system both supports the entrepreneurship, then there would be good number of entrepreneurs in the future". While matching the qualitative data as a whole with the empirical results of this study, it was found that, there is a weak relationship between SMEDA SME policies and development of entrepreneurship, however, the relationship is significant in nature. It was also found that, there is a weak relationship between cultural tendency and development of entrepreneurship in Pakistan, however, the relationship is significant in nature as well. Moreover, it has discovered through the two statistical tests that, there is a weak relationship between private educational institutions' capacities and development of entrepreneurship; however, the relationship is significant in nature. Finally, it was observed that, there is a moderate relationship between cumulative SMEDA policies, cultural tendency, private educational intuitions' capacities and entrepreneurship development in Pakistan. Last but not the least; when the interviewees were asked regarding the overall impact of entrepreneurship ecosystem on the development of entrepreneurship, they pointed out regarding the role of legal framework and incubation centers in the formation of ecosystem by saying that "The role of government is very important because once the startup is growing, it faces so many issues like taxation and other regulatory problems, they impose so many challenging situation that it becomes very difficult for any startup to expand and they eventually are demotivated"-Azad Ahmed. The similar thoughts were shared by Ms. Hanna Lakhani "it takes a long time to open a bank account and transferring money from abroad if someone is coming from abroad and starting his/her own new venture like Roshni Rides. The procedure involves stack of paper work, a stack of finger prints in order to open a bank account and the process is frustrating for new entrepreneurs, this is the basic or prime step to start any new startup and it is quite discouraging, NTN process is also not that simple for new entrepreneur". Similarly Dr. Omar Javaid mentioned "Business registration process is not so easy; you can't do it by yourself, but if you have done it 2 to 4 times, then it becomes easy. However, taxation process particularly is very difficult and you have to take advice from any lawyer". However when asked regarding the role of incubation centers Mr. Ahmed Hassan gave his opinion by mentioning that "Incubation centers are going extra mile, doing very well in promoting entrepreneurship, they are providing platform on national and international level, they provide business place, business leads, provide business strategies". But, Syed Ali 
Taimoor argued "There are $80 \%$ entrepreneurs in some incubation center are IT professionals". Lastly Mr. Shahjahan Chaudhary gave the gist of the discussion by making final remarks that "Entrepreneurship will increase in the country, if Govt. of Pakistan streamlines at least three basic processes like company registration process, bank account opening process and taxation process for new startups". However, while concluding the qualitative part of this study, the six themes emerged from the whole discussion: Family System, Educational System, Entrepreneurial attributes, Legal framework, Incubation centers and societal exposure (Figure 2).

\section{Conclusion}

The research was carried out in order to understand and explore entrepreneurship ecosystem phenomena in terms of SMEDA policies, cultural tendency and private educational institutions' capacities quantitatively and find the influence of entrepreneurship ecosystem on the development of entrepreneurship in Pakistan qualitatively. The study was based on the model made by Daniel Isenberg (2011) through his Babson project and the variables were chosen from the six domains mentioned in that model. The research was a mixed methods convergent parallel kind of study in which both qualitative and quantitative methods were employed to collect data and analyzed in the parallel fashion and then the final results were drawn accordingly as depicted in Figure 3. Although, it was found through descriptive analysis of study that $73 \%$ of respondents have confirmed that the entrepreneurship ecosystem can play a key role in the development of entrepreneurship ranging from $40 \%$ to $80 \%$ in Pakistan. It was also emphasized by $66 \%$ respondents of the study that combination of favorable SMEDA policies, cultural tendency and private educational institution's capacities (entrepreneurs' incubators, training on latest business trends) can help promote entrepreneurship ecosystem and hence support in the development of entrepreneurship ranging from $40 \%$ to $80 \%$ in Pakistan. Furthermore, it was concluded through quantitative data analysis by using Spearman and Pearson correlation methods that, there is a weak relationship between each of the independent variables (SMEDA policies, Cultural tendency, and Private educational

\section{Entrepreneurship Ecosystem in Pakistan}

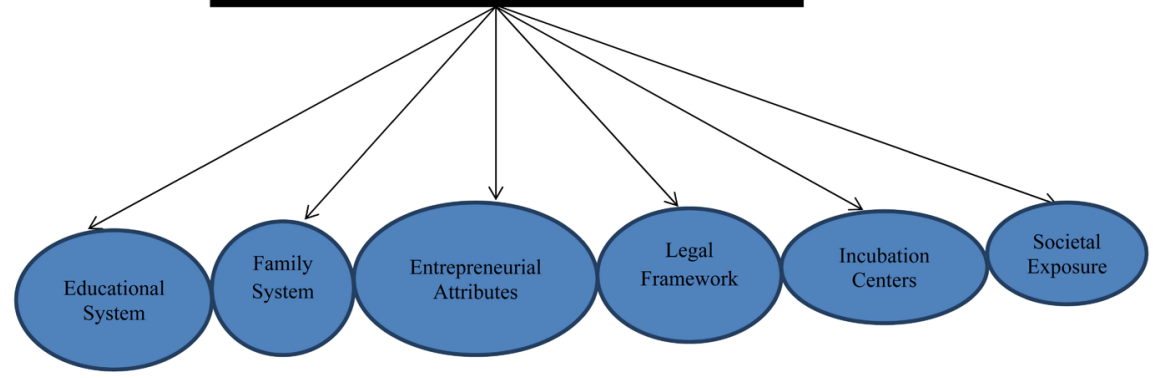

Figure 2. Describing entrepreneurship ecosystem emerged from this study. 


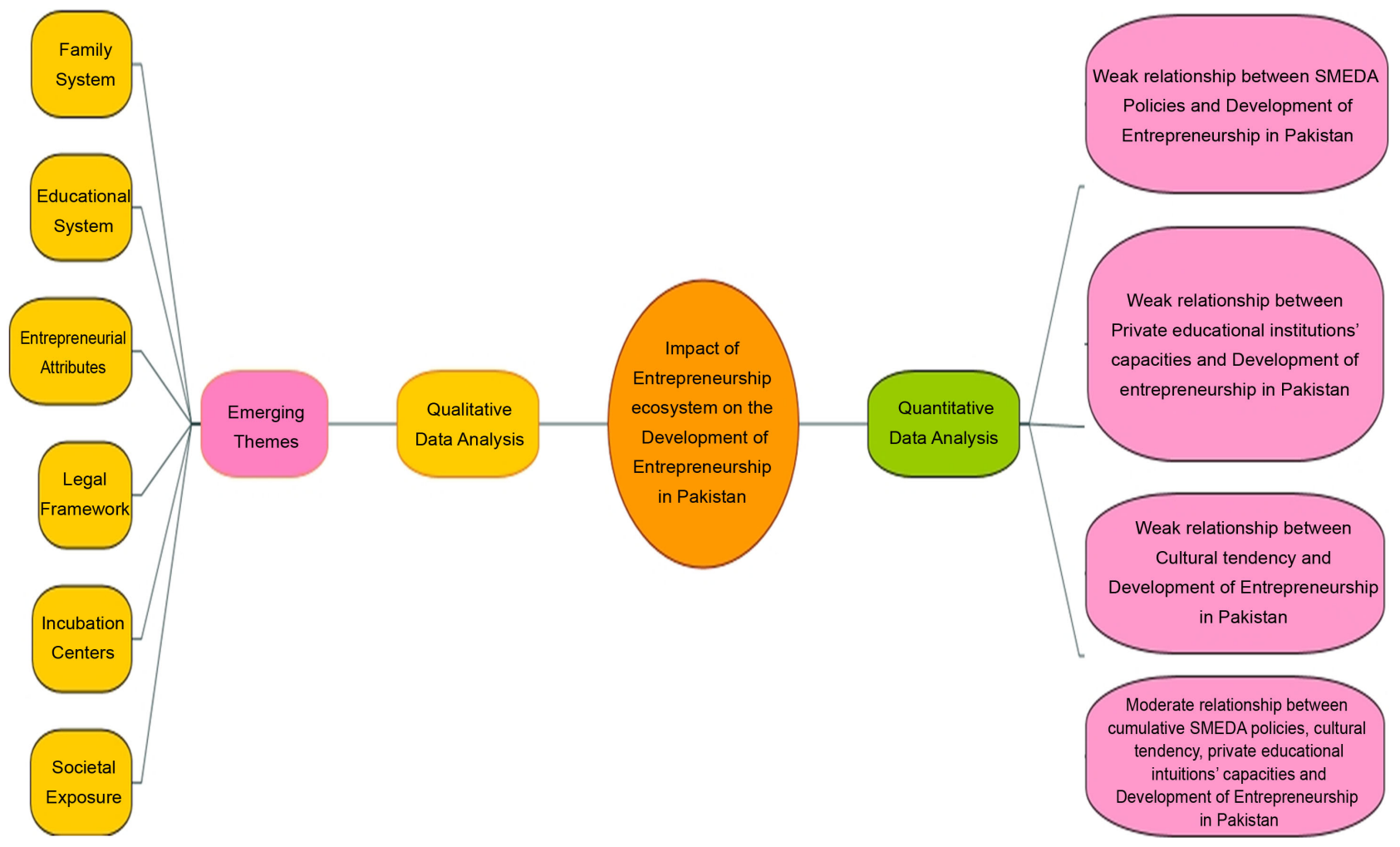

Figure 3. Portraying the final findings of this study including the quantitative and qualitative results.

institution's capacities) and the development of entrepreneurship in Pakistan. Moreover, the nine study interviewers from different backgrounds also endorsed the importance of those three in the development of entrepreneurship, however, stressing the significance of a few more concepts in this regard. It can be exemplified as Dr Omar Javaid (one of the interviewers) mentioned "If family and education system both support the entrepreneurship, then there would be a good number of entrepreneurs in the future". Similarly, Nida Hasan (one of the interviewers) of this study emphasized "Entrepreneurship can increase if there is a system in place that supports the new entrepreneur either through financial support, legal support or support in implementation of their idea through counselors or mentors-who can initially guide an entrepreneur at their initial stage or at least help them in order to run their pilot project". Another respondent (Ahmed Hassan) highlighted the role of incubation centers "Incubation centers are going extra mile, doing very well in promoting entrepreneurship, they are providing platform on national and international level, they provide business place, business leads, provide business strategies". Last but not the least, $\boldsymbol{M s}$. Hanna Lakhani pointed out the role of exposure by mentioning regarding the entrepreneurship clubs at the university level "Those clubs at university level are beneficial. They provide the taste of what the entrepreneurship is, they also do provide the exposure".

Hence, this study concluded at the end that quantitatively, there is a moderate relationship between cumulative SMEDA policies, cultural tendency, private 
educational intuitions' capacities and entrepreneurship development in Pakistan. However, the interview data has culminated into six main factors (Family System, Educational System, Entrepreneurial attributes, Legal framework, Incubation centers and societal exposure) that eventually make an entrepreneurship ecosystem, and may contribute significantly to the development of entrepreneurship in Pakistan. Therefore, it can be argued with some certainty at the end of this research that, by improving the SMEDA policies, so that become favorable to effectual entrepreneurship, making use of private educational institutions' capacities effectively and efficiently and changing the cultural tendency along with supportive legal framework would eventually develop a conducive entrepreneurship ecosystem, that is going to play a key role in the development of entrepreneurship in Pakistan.

\section{Recommendations}

The main purpose of this study was to examine the contribution of existing entrepreneurship ecosystem and its subsequent impact on the development of entrepreneurship in Pakistan; however, while asking the interviewers regarding the modification in the entrepreneurship ecosystem in Pakistan, that may have an impact on the development of entrepreneurship. The interviewers of this study suggested the number of steps to be taken or things to be done as follows:

1) SMEDA should widen up its scope by accessing at each and every level or new department or ministry should be made in order to support entrepreneurship at each and every level (Syed Ali Taimoor).

2) SMEDA, FBR, Intellectual property and other authorities must simplify their procedures (Ahmed Hassan).

3) Entrepreneurship can increase if Govt provides a fixed income to young entrepreneurs as a loan for some time period that covers their personal expenses or it fulfills their basic needs and it is given only, if someone is willing to open a firm legally and that loan is taken back once the firm starts earning (Nida Hasan).

4) Skills + Motivation + Support (majorly from family) is the key formula for successful entrepreneur in Pakistan (Dr. Omar Javaid).

5) Mindset can be changed by starting sending people in "Morning talk shows", there should be discussion regarding career options and what kind of career alternatives are available for children, invite the successful entrepreneurs (e.g. founder of Chotu Chai Wala) and show this to housewives that, entrepreneurship is also the alternative and if you support your child and keep him motivated then, they can be as successful as like any successful entrepreneur (Dr. Omar Javaid).

6) Policies should approach at school level or at gross root level, the course is outdated there and hence, we need to introduce compulsory entrepreneurship course (Syed Ali Taimoor).

7) If the incubation center becomes mandatory in the university premise, then 
it can help primarily to those willing to start their own business, if the helping hand is provided within the university that will help a lot to promote entrepreneurship (Azad Ahmed).

8) If an individual gets support from their education system, family, government, college or universities, SMEDA can promote entrepreneurship; can create entrepreneurship mindset at the end of the day in Pakistan (Hanna Lakhani).

9) The entrepreneurship in Pakistan will increase by streamlining Company registration process, Bank account opening process, Taxation process for new startups (Shahjahan Chaudhary).

10) If Roshni rides get support from government officials in order to brand our cars with our logos, if it becomes easier to access government officials, those all can make Roshni rides more successful and other entrepreneurs as well (Hanna Lakhani).

11) There should be a system in place that supports new entrepreneurs either through financial support, legal support or support in the implementation of their idea through counselors or mentors-who can initially guide an entrepreneur at an initial stage in order to at least run their pilot project. Resources+ Contacts+ Inherent talent is the success equation for any successful entrepreneur (Nida Hasan).

12) It is very difficult to change the entire mindset of education system, but, if we add the successful entrepreneurs case studies in the curriculum, then slowly and gradually, train the teacher and teach them the importance of entrepreneurship mindset, then it will take some time but, the change can eventually happen (Azad Ahmed).

\section{Conflicts of Interest}

The author declares no conflicts of interest regarding the publication of this paper.

\section{References}

Abzari, M., \& Safari, A. (2010). The Role of Culture on Entrepreneurship Development. A Case Study. Iran: Department of Management, University of Isfahan.

Acs, Z. J., Audretsch, D. B., Braunerhjelm, P., \& Carlsson, B. (2004). The Missing Link: The Knowledge Filter and Entrepreneurship in Endogenous Growth. Centre for Economic Policy Research (CEPR) Discussion Paper, London: Centre for Economic Policy Research.

Akhuemonkhan, I. A. (2005). Modalities of Teaching Entrepreneurship in Technical Institution. In National Workshop on Capacity Building for Lecturers of Polytechnics and Monotechnics in Nigeria.

Andrieu, E. C. (2010). The Entrepreneur According to the Austrian School. In Businesses Report OPENS Forum (2014): Study Reports On Growth of Women-Owned Businesses. April 2010.

Banjoko, S. A. (2002). Human Resource Management: An Expository Approach. Lagos: Pumark Nigeria Ltd. 
Bazhal, I. (2017). The Political Economy of Innovation Development: Breaking the Vicious Cycle of Economic Theory. Berlin: Springer. https://doi.org/10.1007/978-3-319-54852-4

Braunerhjelm, P. (2010). Entrepreneurship, Innovation and Economic Growth-Past Experience, Current Knowledge and Policy Implications. Sweden: KTH Royal Institute of Technology.

Creswell, J. W. (2014). Research Design: Qualitative, Quantitative and Mixed Methods Approaches (4th ed.). Thousand Oaks, CA: Sage.

Creswell, J. W., \& Plano-Clark, V. L. (2011). Designing and Conducting Mixed Methods Research. Thousand Oaks, CA: Sage.

Davidsson, P. (1995). Determinants of Entrepreneurial Intentions. Paper Prepared for the RENT IX Workshop, Piacenza, 23-24.

De Jong, J. P., \& Marsili, O. (2010). Schumpeter versus Kirzner: An Empirical Investigation of Opportunity Types. EIM Research Reports.

Drucker, P. F. (1985). Innovation and Entrepreneurship. London: Pan Books Ltd.

Dyer, W. G., \& Handler, W. (1994). Entrepreneurship and Family Business: Exploring the Connection. Entrepreneurship Theory and Practice, 19, 71-83.

Eze, J. F. (2011). Entrepreneurship Education for Self-Reliance and Implications for the Millennium Development Goals. The Sixth International Conference on Development Studies, Benue State University, Makurdi, Nigeria, 2-3 February 2011.

Giz Report (2014). Guide for Mapping the Entrepreneurial Ecosystem. Retrieved from https://c.ymcdn.com/sites/ande.site-ym.com/resource/dynamic/blogs/20180326 16460 6 18189.pdf

Gunter, F. R. (2012). A Simple Model of Entrepreneurship for Principles of Economics Courses. The Journal of Economic Education, 43, 386-396. https://doi.org/10.1080/00220485.2012.714314

Hansen, E. L. (1995). Entrepreneurial Networks and New Organization Growth. Entrepreneurship Theory and Practice, 19, 7-19. https://doi.org/10.1177/104225879501900402

Hofstede, G. (1991). Cultures and Organizations: Software of the Mind. London, UK: McGraw-Hill.

Holton, E. F., \& Burnett, M. F. (2005). The Basics of Quantitative Research. Research in Organizations: Foundations and Methods of Inquiry (pp. 29-44).

Isenberg, D. (2011). The Entrepreneurship Ecosystem Strategy as a New Paradigm for Economic Policy: Principles for Cultivating Entrepreneurship. Institute of International and European Affairs, Dublin, Ireland, 12 May 2011, 1-13.

Jegede, C. T. (1990). The Development of Small and Medium Scale Industry in Nigeria. Management in Nigeria, 26, 8-10.

Johannisson, B. (1988). Business Formation-A Network Approach. Scandinavian Journal of Management, 4, 83-99. https://doi.org/10.1016/0956-5221(88)90002-4

Kayne, J. (1999). State Entrepreneurship Policies and Programs. Kauffman Center for Entrepreneurial Leadership, Ewing Marion Kauffman Foundation. https://doi.org/10.2139/ssrn.1260444

Kern, S. E. (2014). Inferential Statistics, Power Estimates, and Study Design Formalities Continue to Suppress Biomedical Innovation. USA: Cornell University. https://arxiv.org/abs/1411.0919-

Kirzner, I. M. (1973). Competition and Entrepreneurship. Chicago, IL: University of 
Chicago Press.

Larson, A. (1991). Partner Networks: Leveraging External Ties to Improve Entrepreneurial Performance. Journal of Business Venturing, 6, 173-188.

https://doi.org/10.1016/0883-9026(91)90008-2

Laužikas, M., \& Mokšeckienė, R. (2013). The Role of Culture on Entrepreneurship in Lithuania. Socialiniai Tyrimai, 2, 55-69.

Mariana-Cristina, G. (2014). Entrepreneurship, a Solution to Improve Youth Employment in the European Union. Management Strategies Journal, 26, 580-588.

Mason, C., \& Brown, R. (2014). Entrepreneurial Ecosystems and Growth Oriented Entrepreneurship. Final Report to OECD, Paris, 30, 77-102.

Morse, J. M. (1991). Approaches to Qualitative \& Quantitative Methodological Triangulation. Nursing Research, 40, 120-123. https://doi.org/10.1097/00006199-199103000-00014

Napier, G., \& Hansen, C. (2011). Ecosystems for Young Scalable Firms. FORA Group.

Pakistan Entrepreneurship Ecosystem Report (2014). Invest2innovate. http://www.startup.pk/wp-content/uploads/2018/06/i2i-Ecosystem-Report-2016-Final1.pdf

Pickett, S. T., \& Cadenasso, M. L. (2002). The Ecosystem as a Multidimensional Concept: Meaning, Model, and Metaphor. Ecosystems, 5, 1-10.

https://doi.org/10.1007/s10021-001-0051-y

Reynolds, P. D., Bygrave, W. D., Autio, E., \& Arenius, P. (2004). GEM 2003 Global Report. Babson Park, MA: Babson College.

Russell, R. D. (1997). The Impact of National Culture on the Emergence of Entrepreneurship. In USASBE Annual National Conference "Entrepreneurship: The Engine of Global Economic Development”(pp. 21-24). San Francisco.

Saleem, S. (2008). SMEDA SME Policy Paper 2007-A Critical Review: An Analytical Commentary upon SME Policy Proposed by SMEDA Pakistan. MPRA Paper No. 7329. https://doi.org/10.2139/ssrn.1092050

Sarasvathy, S. D. (2008). Effectuation: Elements of Entrepreneurial Expertise. Cheltenham: Edward Elgar Publishing. https://doi.org/10.4337/9781848440197

Schumpeter, J. (1934). Capitalism, Socialism, and Democracy. New York: Harper \& Row

Shane, S., \& Venkataraman, S. (2000). The Promise of Entrepreneurship as a Field of Research. Academy of Management Review, 25, 217-226.

https://doi.org/10.5465/amr.2000.2791611

SMEDA SME Policy (2007). SME Led Economic Growth-Creating Jobs and Reducing Poverty. Ministry of Industries, Production \& Special Initiatives Government of Pakistan.

Stam, F. C., \& Spigel, B. (2016). Entrepreneurial Ecosystems. USE Discussion Paper Series, $16,1-18$.

Teece, D. J. (1987). The Competitive Challenge: Strategies for Industrial Innovation and Renewal. Pensacola, FL: Ballinger Pub. Co.

Tötterman, H., \& Sten, J. (2005). Start-Ups: Business Incubation and Social Capital. International Small Business Journal, 23, 487-511. https://doi.org/10.1177/0266242605055909

Venkataraman, S. (1997). The Distinctive Domain of Entrepreneurship Research: An Editor's Perspective. In J. Katz, \& J. Brockhaus (Eds.), Advances in Entrepreneurship, Firm Emergence, and Growth (pp. 119-138). Greenwich, CT: JAI Press. 
Yaribeigi, E., Hosseini, S. J., Lashgarara, F., Mirdamadi, S. M., \& Najafabadi, M. O. (2014). Development of Entrepreneurship Ecosystem. International Journal of Advanced Biological and Biomedical Research, 2, 2905-2908.

Zafar, A., \& Mustafa, S. (2017). SMEs and Its Role in Economic and Socio-Economic Development of Pakistan. International Journal of Academic Research in Economics and Management Sciences, 6, 1-16. https://doi.org/10.6007/I]ARAFMS/v7-i4/3484 